\title{
A NOTICE ON LENITION AND HARDENING
}

\section{A GARŠUNI SUMMARY ON BG $\bar{A} D K P \bar{A} T$ PRONUNCIATION IN MS SACHAU 196}

\author{
ROBERTO BERTOZZI \\ UNIVERSITY OF PISA (ITALY)
}

\begin{abstract}
This article provides the edition and the translation of a short anonymous treatise about Syriac bgädkpät and written in Garšnni, the "Notice on Lenition and Hardening," which is preserved in MS Berlin, Staatsbibliothek, Sachau 196. The comparison with some of the major Syriac grammars (from Bar Ebraya onwards) is indicative of alignment of the treatise with the traditional native description of Syriac phonetics. Moreover, this shows that it was intended as a summary to be kept at hand and not as a thorough analysis. From a linguistic point of view, the study bighlights a close interaction between the use of Garsuni and the influence of the Syriac milieu. This is clear from the choice of Middle Arabic forms and from the creation of a technical vocabulary under the pressure of language transfer.
\end{abstract}




\section{INTRODUCTION}

MS Berlin, Staatsbibliothek, Sachau $196^{1}$ is an interesting manuscript in many respects. It was copied by Mika ${ }^{2} i^{2}$ who completed it in the month of Šbat of the year 2149 AG (1838 CE). ${ }^{3}$ It consists of 100 paper folios and includes 21 works followed by a list of works by Bar 'Ebrāyā (ff.95r-96r), the colophon (ff.96v-97r), two blank pages, a page filled with pencil and ink notes, the enumerated solutions to the riddles of ff. $21 \mathrm{v}-37 \mathrm{v}$, and finally some other verses on the last page $(\mathrm{f} .100 \mathrm{v})$. The pages are numbered in pencil with Arabic numbers, while there is no quire numeration. The use of a mistara, i.e. a ruling frame employed to create a pattern of blind lines on the page, ${ }^{4}$ appears on some of the leaves. The works are written in Syriac and Garšuni Arabic. The script is a thick serțā disposed in a single column of about twenty-five lines per page, up to f.49r. From f.51v to f.57v, with the Discourse on Divine Wisdom by Bar 'Ebrāyā, the writing area of about twentythree lines is framed at the bottom and along the external margin with additional text in a commentarial shape. Ff.81r-

\footnotetext{
${ }^{1}$ Property of the Staatsbibliothek zu Berlin - Preussischer Kulturbesitz, Orientabteilung. Shelf mark 198 in Sachau's personal catalogue. Cf. Eduard Sachau, Verzeichniss Der Syrischen Handschriften, vol. 1-2, Die HandschriftenVerzeichnisse Der Könighlichen Bibliothek Zu Berlin 23 (Berlin: A. Asher \& Co., 1899), 632.

2 The name is given in the colophon and at the end of the eighteenth text, a poetic composition in the Mār Ya' qōb metre by Basilius, where each line begins with a semkat and rhyme in $\overline{a s}$, except for the last four lines, that rhyme in as and are an addition by the scribe himself. He reveals his name through the numerical value of the Syriac letters: "A fool and evil one, who has taken refuge in the name of Yah, wrote, revised and set in order this poem at the top of the sheet. He also arranged his name in those lines and took refuge in Christ. He did and contracted his name in the forty, in the ten, in the twenty and in the one" (f.60r). The riddle gives the name Mikā, which is - as stated - a contracted form of Mikāail.

${ }^{3}$ Cf. the colophon and the scribal note at the end of the hymn on $\mathrm{f} .61 \mathrm{v}$, which was copied in Tešrin Qdem of the same year (October $1837 \mathrm{CE}$ ).

4 Adam Gacek, Arabic Manuscripts: A Vademecum for the Readers, Handbook of Oriental Studies. Section 1, The Near and Middle East 98 (Leiden, Boston: Brill, 2009), 231-32.
} 
$84 \mathrm{r}, 85 \mathrm{r}-86 \mathrm{v}, 87 \mathrm{v}-90 \mathrm{v}, 95 \mathrm{r}-94 \mathrm{v}$ show a double-line frame. On ff. $91 \mathrm{r}-94 \mathrm{v}$ there is some blank space left over at the bottom and at the external margin, seemingly reserved for comments and glosses. Besides sertā, the Arabic script is sporadically used too, not only in some notes on the last folio but also inside the texts. ${ }^{5}$ The ink is black, with several rubrics and an irregular use of red diacritical dots. The notation of Syriac and Greek vowels is inconsistent. There are some geometrical and inaccurate band-decorations, especially at the beginning (e.g. f.73v) and at the end (e.g. f.40v) of a text.

In the colophon, the scribe says that the book was "at first Abü'l-Ma'ānī, the Book of Riddles, [the Book] of the Pupil and the Discourse of Wisdom by the theologian Mār Gregory ${ }^{6}$ the mapryän $\vec{a}$ ' (f.96v 1l.6-8). If the adverb qadmä it is understood as 'at the beginning', the sentence is not particularly significant. On the other hand, if we consider it to mean 'initially' in a temporal sense, it casts some light on the slightly discordant content of the manuscript itself, by underlining the fact that originally it was meant to consist of only the aforementioned works. In fact, in addition to these, the manuscript includes a number of hymns and other poetic liturgical compositions, as well as the grammatical treatise which is the focus of this paper, and a prayer against toothache. We might then suppose that all these additional works should have been included in the anthology during the copying of the main texts. Indeed, they are placed after the Book of Riddles but before the works by Bar 'Ebrāyā, thus breaking off the original sequence. This would mean that the manuscript copied by Mikâjil-if it did ever exist, and if Sachau 196 is not an original anthology—consisted of only Abū'l-Ma'ānī and Bar 'Ebrāyā's works, which would be an intriguing match.

${ }^{5}$ E.g. in the Abū'l-Ma'ānī’s Sullāqa häwnānāyā, f.14v 1l.7-8, where the Arabic translation of a chapter's title is written right after the Syriac version. In the same text there are unexpected transitions from Syriac to Garšuni, e.g. in f.11v, 1l.8-14, f.12v 4-16 and f.13v.

${ }^{6}$ Which is, of course, the thirteenth century well-known erudite high prelate and polymath Bar 'Ebrāyā. 
Against the background of the predominantly spiritual content of the manuscript, the short anonymous grammatical treatise in Garšuni stands out. It bears the Syriac title Zubhārā mettol rukeākea w-quššàya (A Notice on Lenition and Hardening) and goes from f.39v to f.40v. Ff.39v and 40r consist of 25 lines each, f.40v of only 18 lines which are organised, from the sixth onwards, in a reverse triangular shape resembling an Arabic colophon and are bordered in red. Each of them begins and ends with a black dot. On the sides of the penultimate line are written, in red, the words tarahhamnà 'ala al-kuttäb, while the last line shows only an isolated àlap as vertex. At the bottom of the text (slightly below the middle of the folio), there is a black and red band decoration with a stylised spiral design framed with dots. The Syriac title is written on the top of the first folio, outside the writing frame, and is fully vocalised with Greek vowels. Red rukkeakkāa and qušsáaya dots are extensively used not only in the Syriac examples explaining the phonetic rules, but also to distinguish different Arabic phones represented by the same Garšuni letter. ${ }^{7}$

As the title says, the treatise is about the phenomenon of lenition of the bgädkpät consonants, i.e. six consonants that can be pronounced either as plosives or fricatives. In the beginning, it is stated that the correct pronunciation of these consonants is recommended for the sake of the "rectification of speech and its elegance" (tașhịh al-kalam wa saqlih, 1.2). The reading, then, becomes easy, smooth and flowing; without the proper pronunciation, it would be harsh and difficult. We can compare this statement with what Bar 'Ebrāyā says in his Book of Elucidations about the function of lenition:

Two are the causes of lenition and hardening, [one which is] necessary and [one which is] suitable. $^{8}$ It is necessary when this script is

\footnotetext{
${ }^{7}$ See section 5 for some linguistic considerations on this subject.

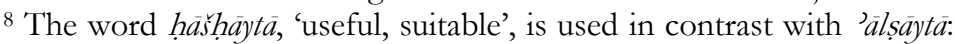
this is 'necessary to the sense', the former is 'used for the sake of elegance'.
} 
complete, like other scripts, with those letters, thus homographs are distinguished in it as much as possible [...]. The suitable cause is when the language possesses ornament and elegance.

We can notice here the parallelism between the Garšuni text and the one by Bar 'Ebrāyā: the Syriac 'ornament' is replaced by 'rectification', but 'elegance [of the speech]' is retained. The similarity between the two definitions is so striking that it can be argued that the anonymous author of the treatise must have had in mind Bar 'Ebrāyā's statement. Or, at least, it had become a standard definition for the bgädkpāt phenomenon. The absence in the Notice of the phonematic argument explained by the Syriac Orthodox mapryana cannot be considered an indication of its incompleteness on the matter. In fact, this theoretical subdivision is not even applied to the exposition of the phonetic rules in the Elucidations. They are basically descriptive and do not explain whether specific instances of lenition are the result of phonematic distinction between homographs or of orthoepy.

In this paper, besides the edition and English translation of the Notice, I intend to point out those contents and linguistic phenomena which are relevant to the history of Arabic language and Syriac grammatical tradition. I do not expect to be able to understand and solve all the problems posed by the treatise, nor to grasp its full implications within each discipline. Instead, this paper is meant to make the modest discovery of the Notice available to competent experts in both fields for further study.

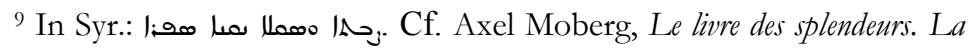
grande grammaire de Grégoire Barhebraeus. Texte syriaque édité d'après les manuscrits avec une introduction et des notes, vol. IV, Skrifter Utgivna Av Kungliga Humanistiska Vetenskapssamfundet i Lund (London, Paris, Oxford, Leipzig: Humphrey Milford, Édouard Champion, University Press, O. Harrassowitz, 1922), 210-11. 


\section{Content of THE Notice}

After the definition of the importance of the correct pronunciation of the bgädkpatt, the description of the subject seems to be significantly in line with the traditional native exposition of Classical Syriac phonetics. The structure is quite simple: the statement of each rule is immediately followed by some examples, introduced by the Syriac word ayk preceded or not by the Arabic expression ka-nahw qawlika. Sometimes there are few exceptions which are explained as a separate rule or otherwise introduced by the Syriac phrase sțar men 'except for'. It will be now provided an overview of the content.

The first rule (11.14-23) is the most basic one. A bgädkpāt becomes fricative in initial position whenever a one-letter proclitic preposition (a so-called bdul) is prefixed to it. The examples take into account each preposition added to a noun for all the bgädkpät consonants, with the exception of $p \bar{e}$. This latter is dealt with separately, in 11.23-31, because it can have a third pronunciation which is called in Arabic mufarqi'a 'explosive', usually referred to in Syriac as pé yawnaytā, 'the Greek $p \vec{e},{ }^{10}$ and which is completely unaspirated. ${ }^{11}$ The rules governing the pronunciation of $p \bar{e}$ are slightly different from those which apply to the other bgadkpät. From the examples, it is clear that the fricative $p^{-}$has to follow a vowel and be itself vowelless and it cannot occur at the beginning of a word. It is also stated that the $b d u l$ have no influence on the lenition of an initial pee, the only exception being the biblical form ba-psilatata.

${ }^{10}$ Cf. e.g. Moberg, IV:210.

${ }^{11}$ Rubens Duval, Traité de grammaire syriaque (Paris: F. Vieweg, 1881), 3032; Theodor Nöldeke, Compendious Syriac Grammar, translated by James A. Crichton (London: Williams \& Norgate, 1904), 10. I deeply thank the anonymous reviewer for pointing out also the following: R. Voigt, "Das Emphatische p Des Syrischen," Symposium Syriacum VII, Orientalia Christiana Analecta, 256 (1998): 527-37; Aaron Michael Butts, Language Change in the Wake of Empire: Syriac in Its Greco-Roman Context, Linguistic Studies in Ancient West Semitic 11 (Winona Lake: Eisenbrauns, 2016), 8184; Aaron Michael Butts, "The Integration of Consonants in Greek Loanwords in Syriac," Aramaic Studies 14 (2016): 18-20. 
Overall, the rule is quite confusing, since it speaks of a "fricative $p \vec{e}$ " which "cannot be spirant". Either the writer confused mutaharrika with murakkaha, or he was mistaken and blended together more than one rule. If this were the case, it could be considered an instance of scribal error of which we will see more further on in the paper. As far as the plosive allophone is concerned, it can occur at the beginning of a word and must be vocalised. Finally, the Greek pé can occur in any position but is of course limited to Greek loan words. Although it is not specifically stressed here, it does not follow the common Syriac phonological rules.

Lenition across word boundaries is presented in lines 3136. It depends on the presence of a final vowel-letter-i.e. an

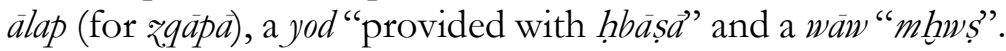
The interpretation of this latter term will be dealt with in the paragraph on linguistic interference. However, according to the examples, it seems in this instance to refer to the semivowel waw of the diphthong aw This can be inferred from the pointing of the examples, and specifically by the ptāha $\bar{a}$ vowel on the last radical of the words preceding the pronoun $b u$ and by what seems to be a linea occultans on the be of each pronoun. In any case, this would be quite unusual in the context of the modern tradition of pronunciation, because generally the presence of a diphthong prevents the lenition. In lines 37-45 it is said that the same vowel letters (and "simple" vowels not accompanied by a mater lectionis, as in the examples, as well) cause lenition also in the middle of a word, unless a vowelless consonant comes between the vowel and the bgädkpät, with some exceptions for the feminine taw ending. It is also interesting to note the allusion to the plosive pronunciation of a vocalised bgädkpāt after a vowel $s s a ̣ s a \bar{a}$ (a vowel noted by wāw), which we would rather explain as a case of gemination. Finally, among the examples, it is surprising to find the words surțā and burketā, that have a rés after the wāw rather than a bgädkpät. They may be remainders of a different rule, either not copied intentionally or accidentally overlooked, which might be another example of scribal error. 
Furthermore, the rule explained at lines 45-50 with reference to vowel letters is ambiguous as the Arabic text is not easy to understand. The rule refers to the connection between a bgädkpät following a vocalised consonant, and an alap that is called uhräniyya, which might mean 'coming at the end, last' or 'second, following'. From the examples, we can argue that the adjective uhräniyya refers to an älap which is (or has become) mater lectionis for a $q . \bar{a} p \bar{a}$, but also to a z.qāpa not marked by an alap. The influence of a rqāpa on the lenition is seen in the plural too, especially for the feminine nouns when compared with their singular which has an occlusive pronunciation instead (i.e. $-\bar{a} t \bar{a}$ against $-t \vec{a}$ ). However, the examples consider also masculine names whose last consonant is not preceded by a zqāpa . Therefore, the rule cannot refer strictly to the emphatic case ending, otherwise the distinction between singular and plural would fail. We should thus assume that the treatise is inconsistently summarising and overlapping several situations into only one explanation.

Dental consonants are discussed in lines 50-56. In the first place, it seems that the treatise refers to the case when a dental (tâw or dälad) is added to a first vowelless täw-in a reflexive form or when the relative pronoun is used. The consonant placed before is pronounced as a plosive, whereas the first radical becomes fricative. The rule is expanded considering the addition of a $b d u l$ to the already existing dental cluster: the plosive pronunciation of the first dental does not change, even if it is preceded by a vowel, and neither does the fricative pronunciation of the second one. A different situation takes place when two bdul, i.e. firstly a dälad and then a wāw before it, are placed at the beginning of a word with a vocalised taw as first radical. Both the tâw and the dàlad are pronounced as plosives, and the text states that this happens because of the wāw vocalised in ptāhă.

The last rule (11.56-63) says that a vocalised bgädkpāt occuring after another vocalised consonant must be plosive. Otherwise (the bgädkpät being vowelless) it is fricative. It is interesting to note that this is not explained in terms of 
gemination but of actual hardening of the consonant, suggesting that by the date of composition of the Notice the knowledge and the perception of gemination might be already lost in western Syriac. The last six lines put an end to the treatise abruptly, stressing again the need to understand the rules described and, as usual, thanking God for his help and asking for forgiveness.

\section{THE Notice AND THE Syriac Grammatical TRADITION}

From the overview above, we can see that the Notice does not cover in full the subject of bgädkpät consonants and it simply puts aside several details. Indeed, the intention of the author might have been not to give a complete description of this aspect of Syriac phonetics, but rather to provide his reader with a basic understanding of it. This becomes clearer when we compare the content of the Garšuni treatise with that of some of the major native Syriac grammars. This allows us to highlight the similarities and the differences and to clarify the place the treatise occupies in that tradition.

In the Metrical Grammar by Bar 'Ebrāyā (Syr. Ktābā dgramatiqi, MS Biblioteca Medicea Laurenziana, Or. 298), the rules concerning the lenition of bgädkpät consonants are split in two parts. The first deals with the letters that become fricative in names, the second with those that become fricative in verbs. This partition is not shown in the treatise, but we can note that almost all the examples are drawn from nouns and only two from verbs. Except for few dissimilarities, among the rules set out by Bar 'Ebrāyā, one can find all those mentioned in the Notice. A first discrepancy is found in the discussion about the pronunciation of an initial non-Greek $p e \bar{e}$ when a $b d u l$ is prefixed. Bar 'Ebrāyā says that this pē undergoes lenition, while the treatise contradicts this and quotes the biblical $b a$ psilätā as an exception. However, in the Metrical Grammar this is just one among many examples of the main rule. On the same subject, the treatise is quite clear about the fact that "a 
vocalised $p^{\bar{e}}$ is not fricative"; ${ }^{2}$ Bar 'Ebrāyā, instead, acknowledges some exceptions to this rule. ${ }^{13}$ The Metrical Grammar addresses lenition after a vowel letter, i.e. yod ḩbiștā and wāw da-'sisutā, as the treatise does, but the former makes no mention of cases where the vowel letter falls before a first radical bgädkpät-i.e., lenition beyond word boundaries. Conversely, the Notice deals specifically with this in its second section and only then moves on to discuss the case of when the vowel letter falls in the middle of the word. The remaining contents of the treatise are addressed in the Metrical Grammar in a very similar way. Bar 'Ebrāyā, however, even in this highly abridged poetical dissertation, discusses more rules, e.g. those related to the Greek kāp, to the personal pronouns beginning with käp suffixed to plural nouns and to the hardness of a tän following a diphthong ay.

The other and more thorough grammatical work by Bar 'Ebrāyā is the Book of Elucidations (Syr. Ktābā d-șemhẹe). Here, the very same rules are expounded with additional explanations of several exceptions. Worth noting where within the text the subject of lenition/hardening of the feminine taw in singular and plural forms of the noun is addressed, ${ }^{14}$ similarly to lines 47-50 of our treatise. In the latter the rule involves not only the tâw of feminine nouns but also every other third radical bgädkpāt. On the other hand, Bar 'Ebrāyā acknowledged this as a feature belonging to the eastern Syrians only: "The eastern [Syrians] also pronounce zalga marga 'esbà with hardening of gämal and bèt, as zalgè margè 'esbe with lenition of gämal and $b \bar{e} t^{\prime} .{ }^{15}$ The following elucidation is quite interesting too as it states that those nouns which have a plosive third radical in the emphatic state have the fricative allophone in the 'contracted' form (Syr. gdāmà, i.e. the absolute and construct states). For

12 ليس فا متحرّكة تكون مركّخة (line 30).

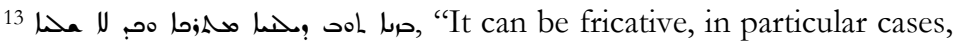
also when it is not silent" i.e. when it is vocalised (cf. Or. 298 f.23r).

14 Moberg, Le livre des splendeurs, IV:210. Cf. in particular lines 16-20.

15 Ibid. 
some of these names, the Notice approaches the issue differently and says that the plosive pronunciation of the third radical depends on the presence of a preceding vowelless consonant in the emphatic state (1.40).

In correspondence with the third section of the Garšuni treatise, regarding the rules of lenition after a vowel, we can find a similar section in the Elucidations. ${ }^{16}$ However, in the Elucidations the analysis is more thorough-compared to that of the Metrical Grammar - and investigates a greater number of instances and nominal categories, mainly arranged on the basis of the number of consonants the names consist of, and the place and kind of vowels that are used. For example, it discusses the nouns consisting of four consonants and two vowels, including those with the feminine taiw ending. And, as in the fourth section of the Notice, the taw is generally considered plosive (like any other third consonant in names with a $\mathrm{C}_{1} \mathrm{VC}_{2} \mathrm{C}_{3} \mathrm{~V}$ scheme) with some exceptions. The list of possibilities, based on the consonant-vowel pattern, is huge. In the treatise, they are either summarily quoted as particular instances or, for the most part, not mentioned at all.

Closer to the time of the Notice ${ }^{17}$ are the didactic works by the Maronite patriarch Ğirğis 'Amīra and the Syriac Catholic Archbishop of Damascus Joseph David. 'Amīra, ${ }^{18}$ three centuries after Bar 'Ebrāyā, preserves in his grammar the traditional organisation of the subject: lenition and hardening are treated in several chapters, depending on whether they occur in the noun or in the verb. The influence of Bar 'Ebrāyā is clear from his presentation of the two causes for the lenition phenomenon, which are the necessity to distinguish between different words and the elegance of speech: "Two causes might be distinguished for the words to be affected by lenition and hardening. The first is that in this way the words can be

\footnotetext{
${ }^{16}$ Ibid., from p.211, 10 onwards.

${ }^{17}$ At least, up until the time of the Notice preserved in MS Sachau 196.

18 Ğirğis Mihā̄̄il 'Amīra, Grammatica Syriaca sive Chaldaica (Roma: Giacomo Luna, 1596).
} 
distinguished one from the other. Sometimes in fact one can find words that, in consonants and vowels, are so similar that if you remove from them the lenition and hardening, you also necessarily remove from them any distinction. [...] The second is for the sake of the refinement, embellishment and pleasantness of speech". ${ }^{19}$ He then continues in the traditional way, going through several possibilities which arise according to the number of consonants in the word, the position occupied by the bgädkpät and the vocalic pattern.

On the other hand, David, ${ }^{20}$ who wrote in the nineteenth century, adopts a completely different perspective on the matter, more in line with the modern tradition. He says that after a vowelless consonant a bgädkpät "remains" hard, whereas after a vocalised letter it becomes fricative except for a double consonant which is always hard. It is interesting to note that he takes into consideration the etymology of the word through comparison with Arabic, and states that the consonant becomes fricative also when it is preceded by a theoretical short vowel, i.e. a short vowel deleted in a pretonic open syllable (this is the vowel deletion rule, characteristic of Aramaic phonetics): "But if the preceding letter is theoretically vocalised with a short vowel, then hardening does not happen, as in bardā barad in which the rếs is theoretically vocalised". ${ }^{21}$ Further on, he also speaks of a "uocalem breuem subintellectam"22 (implied short vowel) which causes the

19 "Duplex autem assignari potest causa, cur uoces lenitate et asperitate afficiantur: prima, ut uoces ab inuicem distinguantur: interdum enim reperiuntur uoces ita similes in litteris, et uocalibus, ut si ab ipsis mollities, et durities tollatur, tollatur etiam necessario ab eis omnis distinctio. [...] Secunda causa est propter elegantiam, ornatum, et suauitatem pronunciandi". Ibid., 124-26.

20 Clemens Joseph David, Grammatica aramaica seu syriaca philologice exposita juxta utrumque systema, orientale scilicet et occidentale (Mosul, 1896).

21 "Sed si littera praecedens est uirtualiter mota uocali breui, tunc asperitas non habet locum, ut بَرَد حَنٌُ in quo resh est uirtualiter motum”. Ibid, 569.

22 Ibid., 576. 
lenition of a following bgädkpät. He is using the šwa argument to explain lenition after a quiescent consonant, whereas Bar 'Ebrāyā explained it through the word-pattern. This is of course predictable, considering David adopted a comparative approach to the Semitic languages. The rest of his treatment of the subject follows more or less the traditional discussion, whereby all the classes of cases in which the rules do not always apply (e.g., with the feminine tāw or in the defective verbs) are enumerated. The same listing method, based on the position of the consonants and on their vocalisation, is maintained by other late grammarians such as Jeremiah Maqdisi $\overline{1}$ and Alphonse Mingana. ${ }^{23}$

In conclusion, the description provided by grammarians of the bgädkpāt issue underwent a considerable degree of standardisation both in its form and content. The rules, as might be expected, are expressed in extremely similar terms. Furthermore, in many cases, the examples too are the very same. Thus, the effort to understand if the Notice has some kinds of (direct) relation with an earlier work becomes difficult. The text itself does not present any evidence of error or correction, with the exception of line 23. Here the scribe mistakenly began to present two examples for the letter $p \bar{e}$, but he crossed them out and went back to discussing the rules of $p \bar{e}$. This leads us to assume that the scribe was copying something and not actually composing the short treatise himself. $^{24}$ Moreover, the addition of a Syriac title outside the writing frame allows us to assert the same, as if the scribe added it later to the anonymous text. I have not been able to identify any original (which might have been longer) or an antigraph.

23 Jeremiah Maqdisī, Grammaire chaldéenne (Mosul, 1889); Alphonse Mingana, Clef de la langue araméenne ou grammaire complète et pratique des deux dialectes syriaques occidental et oriental (Mosul, Paris, 1905).

24 I sincerely thank Professor D. Mascitelli (University of Pisa) for his suggestions. 


\section{LINGUISTIC INTERFERENCE IN TECHNICAL VOCABULARY}

Some considerations about the language of the text will now be attempted. As mentioned above, the Notice is written in Garšuni Arabic, which is Arabic written in a Syriac script. In this case the script used is serțā or Western Syriac. Two main perspectives may be adopted: the grammatical vocabulary in a mixed Arabic-Aramaic context and the non-classical language of the text itself (about which please see the comment to the Garšuni text). The two levels are not completely separated and eventually they interact in leading to some common general observations collected in the conclusions.

The most interesting feature of the grammatical vocabulary of the Notice is the use of what I came to consider calques coined from Syriac and employed to refer to lenition and hardening phenomena. In my opinion, two new Arabic-flexed roots were created on the basis of the Syriac roots RKK and

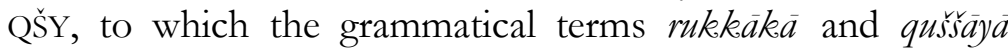
correspond. The first root is given in the treatise as RKH (in Garšuni ,, ;) where $\mathrm{C}_{3}$, a bgädkpāt in Aramaic, becomes an Arabic $h \bar{a} \vec{a}$ and is accordingly written with a Syriac kāp metrakeka. Instead, the second root is given as QŠW. In the text, they are always used in the II and V derived forms. These correspond to the Syriac pacel and etpa "al which are the verbal forms most commonly used with these roots. Thus, we find the verb rakkaha with its passive/reflexive tarakkaha as well as qa šs $\bar{s} \bar{a}$ and taqašsa, conjugated in the finite tenses but also in the participles and masdar.

If we go through some of the most important Arabic dictionaries, we can see that these roots do not occur in standard Arabic, nor does any other root exist which would legitimise the Garšuni spelling. One might wonder if they are specific technical words, not included in the common lexicon but still comprehensible to a native learned specialist. To answer this doubt, one can leaf through Syriac grammars written in Arabic and see what kind of vocabulary they make 
use of. For example, David, in the Arabic version of his treatise, makes a point of explaining the meaning of muqašs and murakkah when he addresses the bgädkpät subject. In fact, in the paragraph where the pronunciation of bet is described, he writes:

This letter is the first among the bgädkpät, all of which have two pronunciations. The first of these is called muqašsa , i.e. which is pronounced with the taqsizyya - i.e., with hardening- ${ }^{25}$ and is marked with a dot above. The other is the murakkah, i.e. which is pronounced with the tarkih -i.e., with lenition- ${ }^{26}$ and is marked with a dot below. ${ }^{27}$

Only few decades later though, Buțros Sābā completely drops the terminology based on Syriac in favour of a purely Arabic one. However, while for the lenition he retains the root LYN already used by David and translates the Syriac metrakk $\bar{a}$ with the Arabic mulayyan, for the hardening he abandons the root ĞFW and chooses to use muqassa $\bar{a}$ for the Syriac metqašy $\bar{a}^{28}$

The fact that in the Notice the Syriac terminology is not explained nor is flanked by clear Arabic synonyms may suggest that the treatise was meant to be used by someone who was already acquainted, to some degree, with the language. It can be argued that it was not intended to have a didactic function,

25 Ar. مُقَشَّىى أي ملفوظًا به بالتقشية أي بالجفآء.

26 Ar. مركّخًا أي ملفوظًا به بالتركيخ أي باللين.

27 Qlīmīs Yūsuf Dāwud, كتاب اللمعة الشهيّة في نحو اللغة السريانيّة على كلا مذهبي الغربيّين .والشرقيّين. Kitāb al-lum'a al-šabiyya fì naḥw al-lugia al-suryāniyya 'alà kilà madhabay al-g̈arbiyyina wa-'l-šarqiyyina (Mosul, 1879), 32.

28 Buțrus Sābā, مرشد الطلبة السرنيّن الى كلتا لهجتي الغربيّين والشرقيّين. Muršid al-țalaba alsuryāniyyina ilà kiltā labğatay al-garbiyyina wa-'/-šarqiyyina (Beirut: al-Maṭa'a alKātūīīkiyya, 1948), 5. 
but rather it must have been a kind of memento, a brief and easyto-use summary of the principal rules related to lenition accompanied by few basic examples. In other words, it was not designated to teach something new but to remind the readers of something they already know. Therefore, explanations of technical vocabulary taken from Syriac would have been unnecessary. In a pure hypothetical way, it can also be assumed that at the time of composition of the treatise (and we only have a terminus ante quem, $1838 \mathrm{CE}$ ) the technical words used were still somewhat clear to the readers, either because they were used extensively in the Syriac grammatical tradition in Arabic (and this deserves further investigation), or because the scholars were supposed to be able to understand both languages.

Another interesting example is to be found in lines 34, 36, 37 and 41 where the rules dealing with a bgädkpät coming after a fully vocalised semivowel, i.e. after a vocalised yod or a vocalised wāw, are explained. In lines 34 and 37, the writer retains the Syriac name of the vowel, hhbassă, and uses the phrases "the yod which has a hhbassă and "the yod which is $h b \bar{a} s \vec{a}^{\prime}$. Yet, when he turns to describe the same rule applied to the waw $w$, he introduces the adjective $<$ '-mhwsṣh $>$ which I have not been able to fully understand. It might derive from the root HȘS which means 'to designate, label, mark'. Thus, it could be understood as a wāw 'marked with a vocalic point, above or below'. Grammatically speaking, the form remains unexplained since it should be al-mahssusșa and we might at least suppose that a metathesis took place between wàw and șäde and forget about the šadda. There is, however, another possible interpretation, which is equally hypothetical. In the text, the parallelism with the yod should be noticed as well as the phonetic similarity between <mḩwșşh> and ḥbāssā. I suspect that the scribe was aware of the fact that sometimes the dots above and below the wāw were called habassa too, ${ }^{29}$ and at least IV:33.

${ }^{29}$ Even in Bar 'Ebrāyā's Ktābā d-ṣemḥè, cf. Moberg, Le livre des splendeurs, 
once, in Severus bar Šakko, the participle ḩbiștā is applied to the fully vocalised waw w. ${ }^{30}$ Therefore, I would not completely dismiss the possibility of reading $<'$-mhwsșh $\rangle$ as al-muhawwișa or al-mahwwissa, which does not exist in Arabic, as far as I know, and would be another neo-coined word based on the Syriac habāṣa or hibiștā. Phonetically, the wàw can be explained by means of the fricative pronunciation of bet, which passed to [w] from [v]. The use of $h$ instead of $h$ is the main counterargument of this hypothesis, although it comes as no surprise, at least from a linguistic perspective. Furthermore, even if the $\check{s} a d d a$ is clearly placed on the șâde, in the treatise it is not infrequent for it to fall upon the consonant following or preceding the doubled letter. Rigorously, the Arabic cognate of the Syriac root HBS is HBȘ, although it means 'to mingle, mix'. In fact, Duval glosses in his grammar the Syriac word habāṣa with the Arabic hafd, which would be more specifically the $i$ vowel when pronounced after the last letter of the word. On the whole, the possibility that the writer, when using the word $<m$ hws ș $>$, still had in mind this web of (phonetic) affinities does not seem completely unreasonable.

Against the background of such an Aramaic environment, the use (only once in line 29) of the Arabic term al-zawa') id is somewhat noticeable. In Arabic grammar, the term indicates every addition (suffixes, prefixes, infixes, prolongation letters and so forth) to the pure triliteral root used for morphological derivation. However, the author of the Notice uses it only to refer to the $b d u l$ consonants-i.e. the proclitic prepositions. When the text addresses the $b d u l$, one usually finds the expression "the four bdul [consonants] are prefixed to...", where the verb for 'to prefix' is saqața 'alä, literally 'to fall upon', which accurately translates npal qdàm, the standard way to express the concept of prefixation in Syriac. In fact, the $b d u l$ consonants are properly known in Syriac as mapplätā those that

30 Albertus Merx, Historia artis grammaticae apud Syros, Kunde des Morgenlandes 2 (Leipzig: Deutschen Morgenländischen Gesellschaft, 1889), p. 
fall'. Why the author chose to use the Arabic al-zawa'id in this case instead of a calque on the Syriac mapplatta is not clear. It is undoubtedly evidence of his deep knowledge of the Arabic grammatical tradition, which does not always match the Syriac one at the theoretical level. ${ }^{31}$ Another significant place from this perspective is the line where the treatise speaks about the 'älap which is second' (alif uhräniyya, 1. 46) —an älap vowel letter or a rqāpa coming after the second radical. This vowel is perceived in a clearly Arabic way like a long fatha, which in Syriac is not always marked with an älap as it is in Arabic. Moreover, the prevalent interpretative frame seems to be the Arabic (based on a pure triconsonantism), since "second alap" refers to a vowel given to the second radical, whereas in Syriac grammar it would refer to an alap in second position in the writing string.

From the analysis of the cases discussed above, it seems safe to say that these instances can be regarded as evidence of linguistic interference between cognate languages spoken and/or used in different social contexts and for different purposes. Syriac was the language of the Church, Arabic the language of the administration and cultural élite. Both of the languages held high-status. This, in turn, led to a two-way interference: of Syriac on Arabic when the author (consciously) uses Syriac lexical material and adapts it to the Arabic environment, and of Arabic on Syriac when the grammatical analysis implies (unconsciously?) an Arabic perspective. The use of calques from Syriac for 'lenition' and 'hardening' may be explained through the existing Syriac tradition and the need to preserve the technical vocabulary, while also bearing in mind that Arabic lacks these phenomena and thus lacks the specific words to describe them grammatically. Conversely, the writer did not need to create a new word to talk about the prefixes and, instead of the mnemonic word $b d u l$, he could make use of

${ }^{31}$ Cf. e.g. Georges Bohas, Approche de l'organisation de la morphologie et de la phonologie chez Bar Hebraeus. Speech given at the $15^{\text {th }}$ round table of the Société d'études syriaques, held on November 17, 2017. 
the extremely technical word al-zawä id and dismiss the Syriac mapplàtā.

\section{A Note ON GARŠUNI AND THE ARABIC TranSCRIPTION}

\begin{tabular}{|c|c|}
\hline Garšuni & Arabic \\
\hline 3 & $s, 1$ \\
\hline ح & ب \\
\hline$\$$ & $\dot{\varepsilon}$ \\
\hline$\$$ & ج \\
\hline$?$ & د , ذ, ض ض \\
\hline ? & ב \\
\hline ? & j \\
\hline$a$ & ه ر \\
\hline$\ddot{a}$ & ة , سَتْ , Lاء \\
\hline 0 & 9 \\
\hline 1 & j \\
\hline מ & $\tau$ \\
\hline$\gamma$ & ط , ظ \\
\hline
\end{tabular}

\begin{tabular}{|c|c|}
\hline Garšuni & Arabic \\
\hline y. & $\dot{\tau}$ \\
\hline$\Downarrow$ & J \\
\hline p & e \\
\hline 1 & ن ن \\
\hline م & س ,ص \\
\hline$u$ & $\varepsilon$ \\
\hline 9 & ف \\
\hline 3 & ص \\
\hline$j$ & ض \\
\hline م & ق \\
\hline ; & ر \\
\hline a & ش \\
\hline$\dot{L}$ & ت ت \\
\hline
\end{tabular}



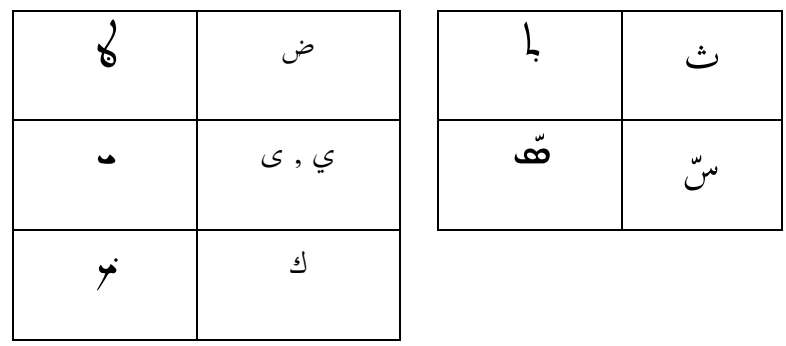

An Arabic transcription is provided along with the Garšuni text for the sake of those who do not read Syriac but nevertheless might be interested in a paper dealing with Garšuni or Christian Arabic topics. However, such a transcription is by necessity unfaithful to the original Garšuni, since it implies a specific interpretation of the text because of its heterographic nature. Therefore, not only does my personal view emerge in the translation, but also in the Arabic transcription. All problematic forms, spellings or linguistic phenomena have been highlighted and analysed in detail in the comment, where I also point out other readings. The reader will find in it more specific information.

It is important to stress that this transcription is not a normalisation at all: all the orthographical features of the Garšuni original have been strictly retained in the Arabic version. No hamza has been restored, no abnormal form corrected according to the fușha $\vec{a}$ s standard, no vowel or any other orthographical sign supplied except for those actually present in the manuscript. A choice has been necessarily made whenever a Garšuni character represents more than one Arabic letter (which is quite a frequent occurrence). However, the reader should not forget that Garšuni is neither a standardised nor a consistent system, and that its actual shape "remains totally dependent on the copyist's cultural background, the tradition of his/her religious community, and the geographical 
location". ${ }^{32}$ This means that Garšuni lacks in consistency not only in general (i.e., there is a high degree of differentiation between all the Garšuni manuscripts), but also within a single text, where one can find several variations.

Many examples of such inconstancy can be found in the Notice. One is the representation of the Arabic $t \bar{a}$ marbutta which is sometimes rendered with a simple Syriac $b \bar{e}$, and sometimes with he with two dots above, like the Arabic character. In addition, this last Garšuni character can also represent any feminine termination, such as the nominal alif mamdìda and the verbal ending -at. Another example is that of the Arabic dedd, which is one of the most unstable graphemes, and is represented by three Garšuni letters. Kessel identified two reasons for this in addressing the core of the Garšuni issue as a whole. ${ }^{33}$ The first is the fact that the so-called Middle Arabic language underwent several changes in its phonetic system, and this shifting can be perhaps reflected by Garšuni texts. The second is the freedom which is felt by the scribe, within certain limitations, to establish his/her own personal conventions.

The correspondences between Arabic and Garšuni graphemes inferred from the Notice are summarised in the table.

\section{TEXT AND TRANSCRIPTION}

$$
\begin{aligned}
& \text { (1) اعلم ايّها الولد المجتَهِد } \\
& \text { في علم النحو لاجل (2) تَصـــحِح } \\
& \text { الكلام وَسَـقلهُ افهم ان سـقل الكلام }
\end{aligned}
$$

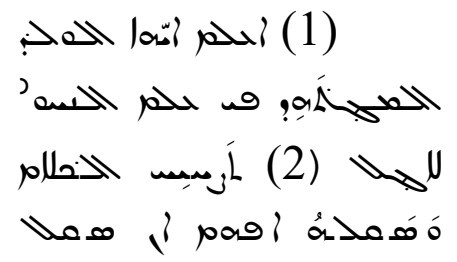

32 Joseph Moukarzel, "Maronite Garshuni Texts: on Their Evolution, Characteristics, and Function" (Hugoye: Journal of Syriac Studies 17:2 [2014]), 253.

33 Grigory Kessel, "The Importance of the Manuscript Tradition of the 'Book of Grace' for the Study of Garšunī”' (Parole de l'Orient 37 [2012]), 14-15. 


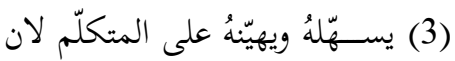
الحملام (3) مسمّحهُ مسمّلهُ

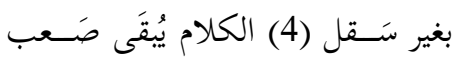

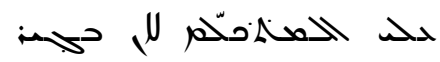
وواقف ومضر: لاجل ذلك وَضَعُوُ (5)

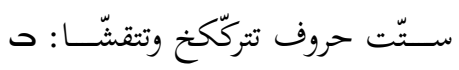

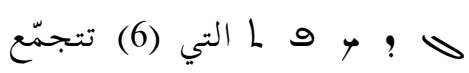
ختربمقهم : ويوضسعوا نُقطَه حَمره ام سَودَه (7) من فوق ام تحت ان كانت من فوق فهِي علامة التقشّي (8) وان كانة من تحتَّ فهِي علامة التركيخ:

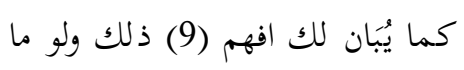
يصير هذا التركيخ والتقشّي كان كثير صعب (10) ولم كنت تقدر تقرا . واذا قريت كان واقف ث: كنحو قوكلك

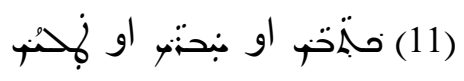
وهَذَا كثير صَعب والسهل (11) تقول

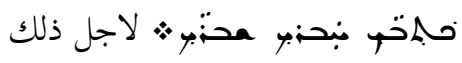
جعلوُ هولاي (13) الســـةّة احروف تتركّخ وتتقشّــي التي بهذه الصــوره:

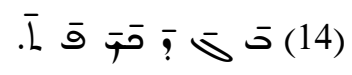
هَملا (4) الخملام هُخَمس زَحد م

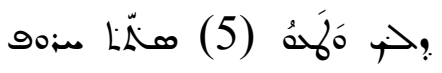

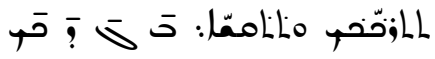
פ

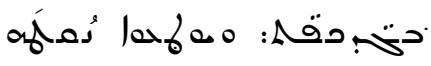

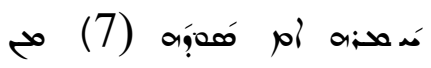

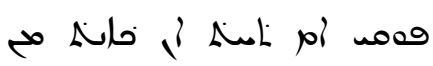

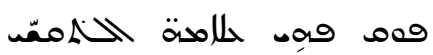

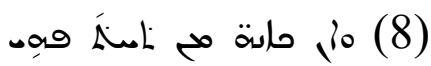

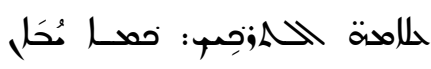

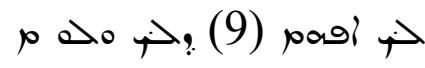

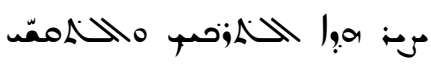

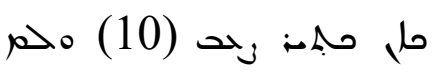

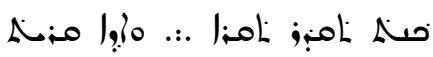

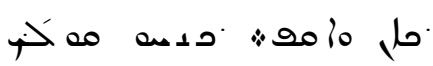

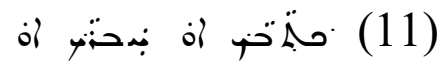

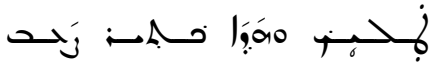
Me ol (12) Ma llo

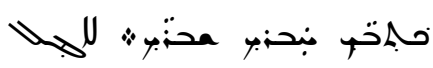
(13) Jlloa álu

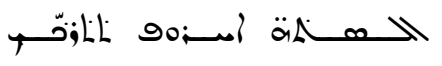

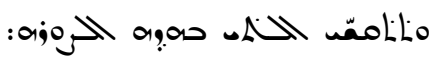

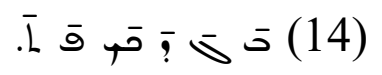


ثم اعلم اذا سقطو على هولا

الســتِت (15) حروف الاربع التي

تتســـمى حبهلا تركّخ الســَّه نَحوُ

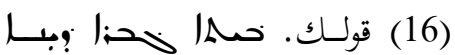

قمها قازقا زإحتا. اذا سقطت (17)

واحده من الاربع حروف على هولا].

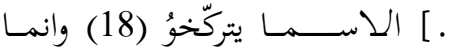

ســقطـت عليهم واحسَهْ من الاربع

حروف يتقشّــــا (19) أهم حهـ

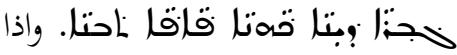

ســـقوُ (20) حروف البدول يتركّخوُ

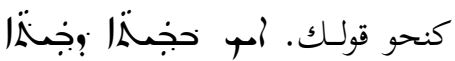

(21) مجِه|

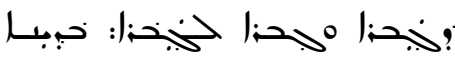

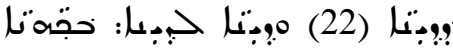

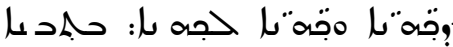

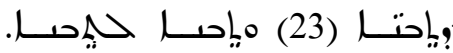

totortoto

واما الفا لها ثلث (24) انواع

واضـراب: تســمى مركخه ومقشّـيه

ومفرقعـه: فـا (25) المركخـه أمب فـا

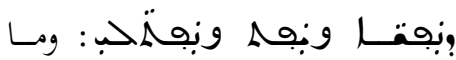

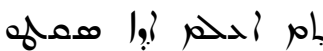

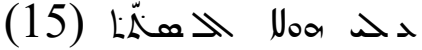

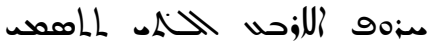

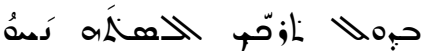

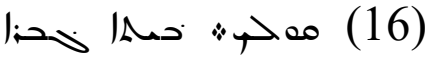

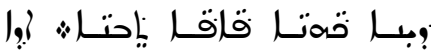

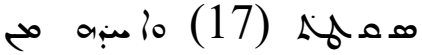

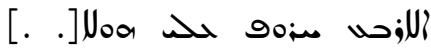

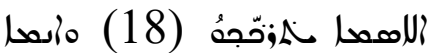

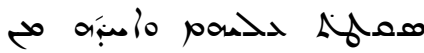

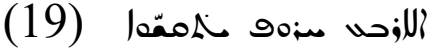

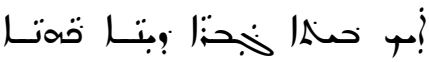

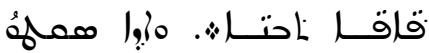

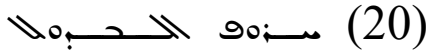

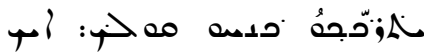

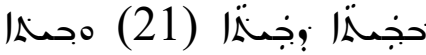

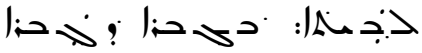

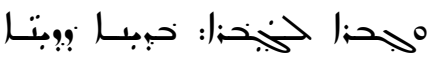
(22) موبتـا حبـــا: حقمتــا

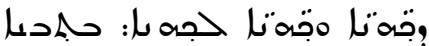

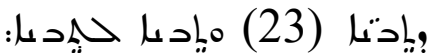
.totog totas مأما الحوا لهما باحي (24)

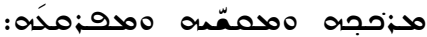

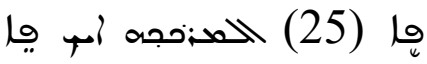

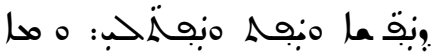


يشـابِه (26) ذلك: وفا المقشـيه أمب

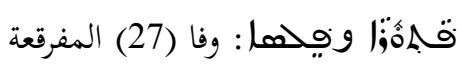

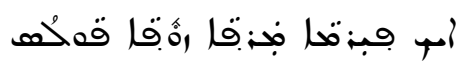
مم:خما: اعلم (28) ان الفا المركّخه لم تقع في اوّل اســـم ولا في الخرهُ: (29) ولم تتركخ اذا ســقط عليه احد الزوايـد الا فـا جوميخهم (30) ثم اعرف ان ليس فــا متحرّكـهـ تكون مركخه بل مقشيه: (31) ولافا ساكنه تكون مقشيه بل مركخه

$$
\text { افهم ذلك: وايضــــــا }
$$

تفهيم اخر اعلم ان اللالف تركّخ اذا سقطَت على حرف (33) من حروف حصبمهم: كنحو قولك: أه أبا فيخ:ا أنا جنتا (34) أنا جنبةا نا باحب:|: كذلك اليود الذي اليها مختا (35) تركخ أه حص هح:ا لح

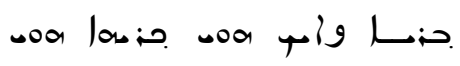
باحن:ا: (36) كذلك الواو المخوصّـــ

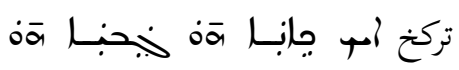
باحب:|: ترغ

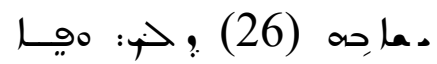

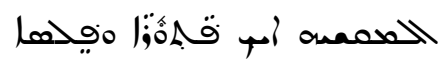

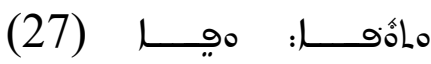

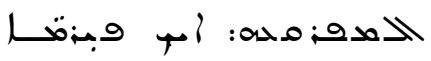

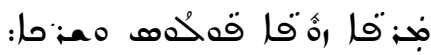

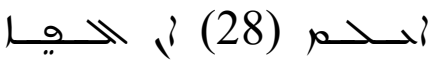

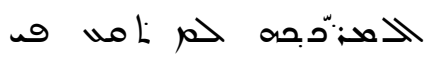
(29)

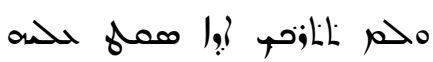

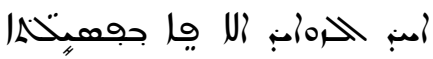

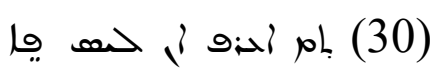

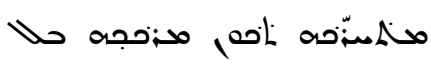
مممسده: (31) ملا يما مازصده

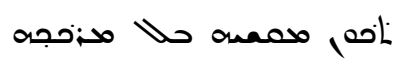
أ

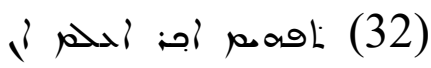

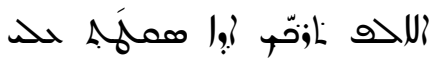
مــ

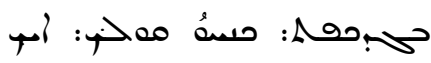

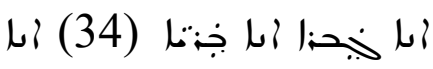

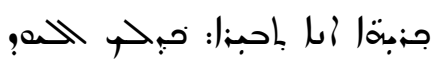
الحب. الحسما مختا (35) Lزته

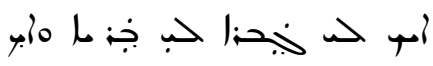

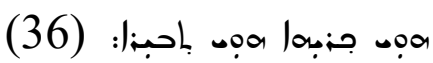

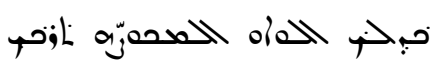

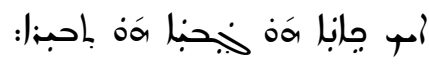


(37) كذلك اليود الوسـطانيَهِ

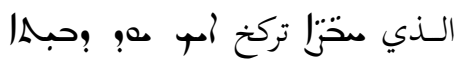

(38)

ح:به| ححب:| ;هبsاء وان كان (39) واحده ســاكته تتقشّــى : أمب

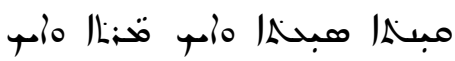

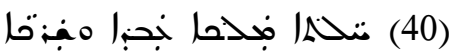

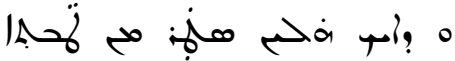

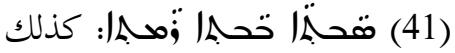
الواو الوســطانيه المخوصــه (42) واو

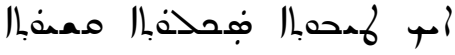

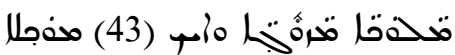
مفيلاء: وانكان قدام الواو حرف من احروف (44) السـته متحرّك يتقشسي

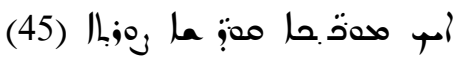
حهزتهم|:

واذا كانت الاحرف متحّركه وســقط واحد من (46) الســته قدام الالف الاخرانيّه تتركخ: أه ملإقا

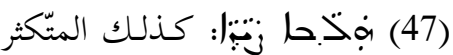
دايم يركخ: أمب وجته| أنيحته| (48) مب:تمب| of

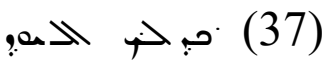

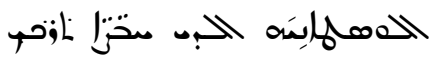

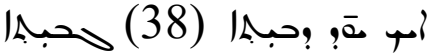

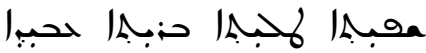
;

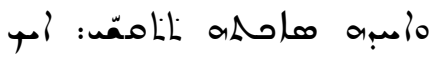

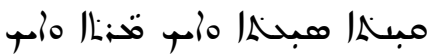

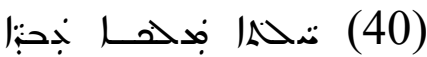

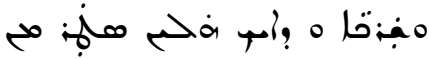

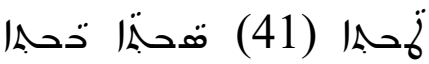

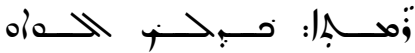

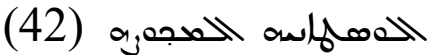
oilo

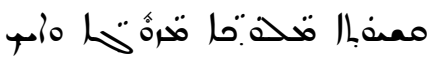
(43) مفجلا مف ليلا: مأنصل

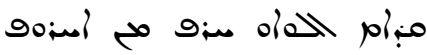

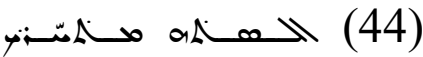

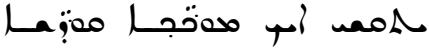

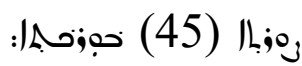


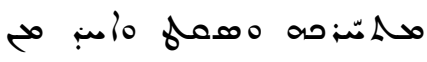

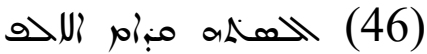

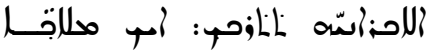

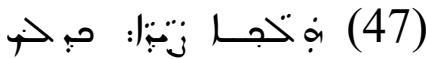

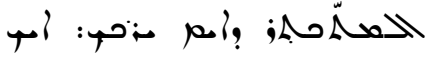
وجتجا إنيحته| (48) مبتمه| of 


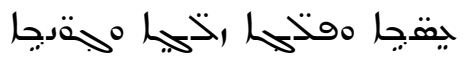

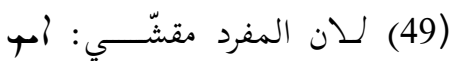

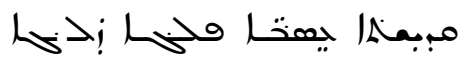
(50)

واذا كانت الثاو ساكته وسقط

عليها دلّذ (51) او تَو تتركخ المتحرّكه واذا سـقطت واحلَه (52) من البذول يتقشّــي حرف الاولاني: أمه (53) مـاوهم منابلمح: واذا كـانـت التـاو متحركه وذخل (54) عليها دلّذ وعلى الدلذ واو اعلم ان الدلّذ (55) تتقشّي:

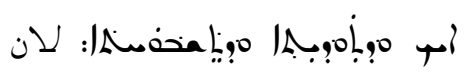
الواو (56) المفتوحه دايم تتقشيث

واذا كــان الـحـرف. (57)

الاولاني متحرك وقـدامـهُ حرف من السـته متحرك. (58) يتقشـي. أمب

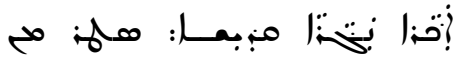

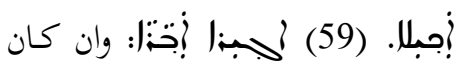
واحد من الستة قدّام. (60) المتحرّك يكون مركخ ايسك فجزلا أجموهما. (61) إجمهتخا أجسبا أجر با: مهلز

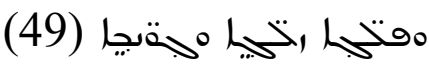
للا

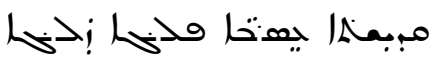
(50)

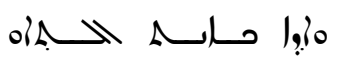

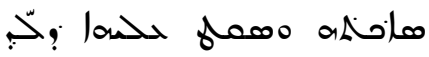


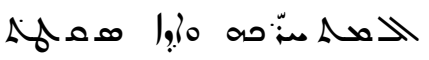

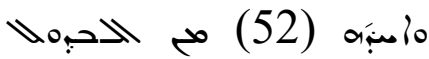

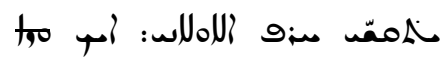

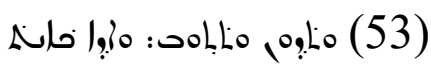

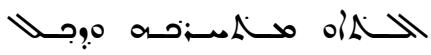

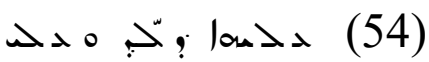
الحتج:

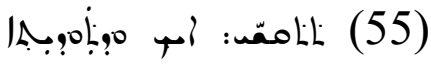

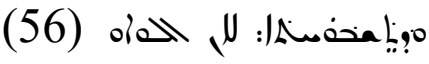
:

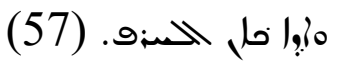
.

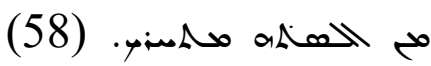

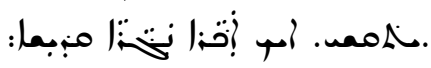

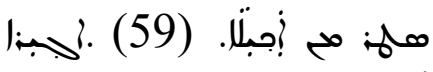
أبخــ":

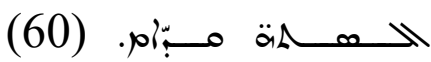

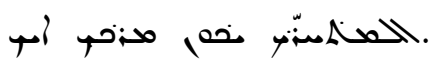
فججلا بأجمودا. (61) .إجمهتنا 


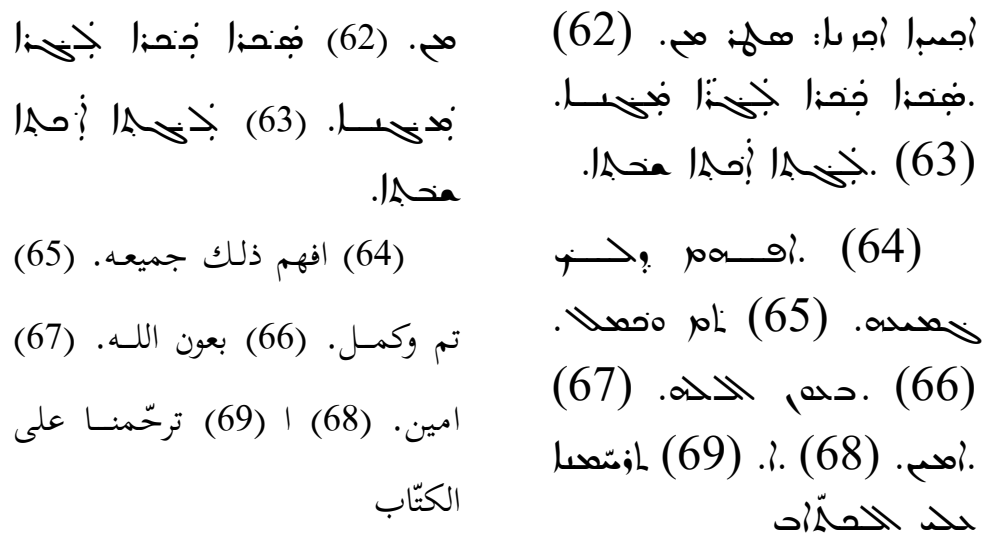

\section{ENGLISH TRANSLATION ${ }^{34}$}

(1) Oh, young men committing yourself with zeal to the science of grammar for the sake of (2) the rectification of the language and its elegance, you need to know and understand that elegance (3) facilitates the speech and makes it easier for the speaker, because without elegance (4) the language is kept hard, difficult and harmful. Because of this, [the Syrians] devised (5) six letters which are pronounced as both fricative and plosive: $\mathrm{b} \mathrm{g} \mathrm{d} \mathrm{k} \mathrm{p} \mathrm{t,} \mathrm{which} \mathrm{(6)} \mathrm{are} \mathrm{brought} \mathrm{together} \mathrm{[in} \mathrm{the}$ mnemonic word] bgädkpāt. A red dot or a black one is placed (7) above or below. If it is above, it is the sign of the hardening; (8) while if it is below, it is the sign of the lenition. You should understand this as it is (9) explained to you. And if these lenition and hardening do not occur, it [i.e. the speech] would be very harsh (10) and you would not be able to read. When you read, it would be difficult [to understand]. If you say: (11) ktäbäk or habräk or talyäk, this is very harsh. It is smooth

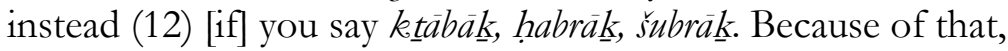
they set these six (13) consonants that become fricative and harden, [and] that have this shape: (14) $\bar{\Xi}, \bar{\Xi}, \bar{\varphi}, \overline{9}, \bar{L}$.

34 In square brackets, additions to the text useful for its full understanding. 
And again, you need to know that when the four [consonants] (15) that are called $b d u l$ are prefixed to these six consonants, the six become fricative. For example, if you (16)

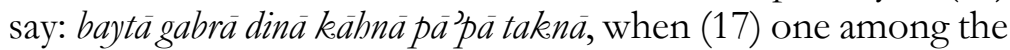
four consonants is prefixed to these names, they are pronounced with the lenition, (18) whereas if one among the four consonants is not prefixed to them, they are pronounced with the hardening, (19) as baytā, gabrä, dināa, keāhnāa, $p \bar{a} \bar{p} \bar{a}, t e \underline{b} n \bar{a}$. And when the consonants (20) $b d u l$ are prefixed to them, they are pronounced with the lenition, as for example $b$-bayta, $d$ -

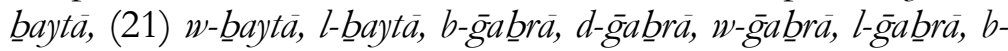

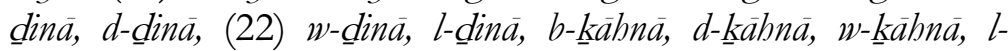

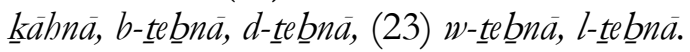

With respect to $p \bar{e}$, it has three (24) kinds and varieties: it is named fricative, occlusive and explosive. The fricative (25) $p \bar{e}$ is like the $\bar{e}^{\bar{e}}$ of naps $\bar{s} \bar{a}$ yapt and naptatili and what is similar. (26) While the occlusive $p \bar{e}$ is like patturā and pelsā. And the explosive

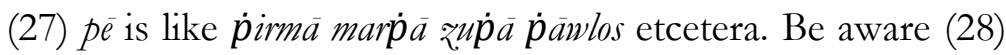
that the fricative $p \bar{e}$ is not found at the beginning of a noun nor at its end, (29) and does not become fricative [sic] when an affix encounters it, except for the $p^{\bar{e}}$ [of] b ba-pisilätā. (30) Then you need to know that there is no vocalised $p \bar{e}$ which is fricative, it is occlusive instead, (31) and the vowelless $p \bar{e}$ is not occlusive but fricative.

You need to know this, and (32) another instruction too. Know that the alap causes lenition when it falls before a consonant (33) among the bgädkpāt consonants, as if you say:

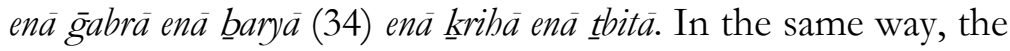
yod provided with a habạsă (35) causes lenition, like lì gabrā lì $\underline{b a r y} \bar{a}$ and like hwi kriba hwi tbirā. (36) Similarly, the vocalised ${ }^{35}$ wàw causes lenition, like kèna-(b)w gabya-(b)w thbirā.

(37) Similarly, the yod in the middle and which is habạsa

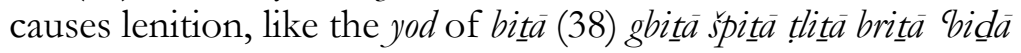
rgig $\bar{g}$. But if there is (39) one vowelless [consonant before the

35 Cf. the chapter on linguistic interference for an explanation of the word which is translated this way here. 
bgäadkpāt], it causes hardening, like qintā si t'à and like mārtā and like (40) hâaltà malkē 'abdà and the rest like them, except for țābtă (41) sābtā bābtā rāmtāa. Similarly, the middle vocalised ${ }^{36}$

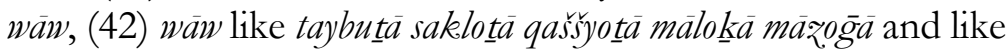
(43) mok la mog̀la. And if right after the wà w there is a vocalised consonant out of the six (44) consonants, it is pronounced as an occlusive, like mukkeāka à quddāšà șurtāa (45) burktāa.

And if there are vocalised consonants, and one out of the six (46) falls after the alap in second position, it is pronounced

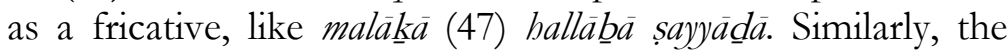

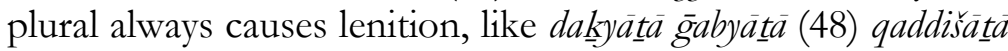

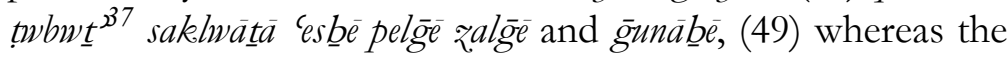
singular causes hardening, like qaddistà 'esbà pelgā ralgā (50) gunbā.

If there is a quiescent tāw and a dälad (51) or a tāw is prefixed to it, they cause the lenition of the vocalised [letter]; and when a $b d u l(52)$ is prefixed, it causes the hardening of the first consonant, like (53) watdun wattub. And if there is a vocalised tâw and a dalad is added (54) to it and to the dalad a waw, be aware that the dalad (55) is pronounced occlusive: like wa-dtäwditāa, wa-d-teśbohtā, because the wäw (56) vocalised with a fatḥa always causes hardening.

If the first consonant is (57) vocalised and there is a consonant from the six after it which is vocalised, (58) it [i.e. the first] causes hardening, like akkearrā, naggārā, qaddišă, except akila (59) a gira a ba ârā. If there is one from the six [vowelless] after (60) the vocalised one, this latter causes softening, like

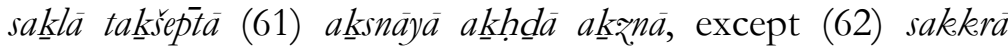

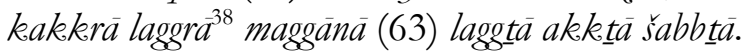

(64) Understand all of this. (65) It has been completed and finished (66) with the help of God. (67) Amen. (68) <älap> (69) We asked mercy for the writers.

${ }^{36}$ See the previous note.

37 I did not understand this word, which may be read as tubwàtāal țobwàtāà.

${ }^{38}$ I was not able to find any reference to this word anywhere, nor did I find a Syriac root LGR. 


\section{Comment to the Text}

\section{2 وَسَقلُ = مَسمَهلهُ}

The word occurs twice in this same line, and then again in line 3. $\mathrm{C}_{1}$ should be a șäd, and the word is saqal 'elegance', but in Garšuni there is always a sin. This phenomenon is well known and attested in Middle Arabic phonetics and the Garšuni manuscript tradition. In addition, in Syriac there is a root SQL with a noun seqla which is perfectly equivalent to the Arabic saqal. ${ }^{39}$ It is not possible to determine if the Garšuni form saqal is due to Middle Arabic phonetics or to the Syriac influence. It might depend on both, as it occurs elsewhere. ${ }^{40}$

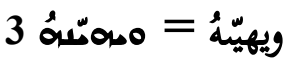

This should be yubawninubu, the II form imperfect from the root HWN, but the Garšuni clearly has a middle yod with a šadda, making theoretically impossible for it to be a II or a IV form of a hollow verb. Moreover, if it were a IV form yubinubu, the meaning would not fit ('to humiliate, mortify, despise'). The presence of a $\mathrm{C}_{2}$ yod in the D-stem of hollow verbs (even those in waw w) is typical of Syriac. There are examples of this in the Arabic dialect of Mardin. ${ }^{41}$

${ }^{39}$ See the introduction for its use by Bar 'Ebrāyā in a similar context.

40 Joshua Blau, A Grammar of Christian Arabic. Based Mainly on South Palestinian Texts from the First Millennium. Fasc. I: $\iint \mathcal{S}$ 1-169. IntroductionOrthography \& Phonetics-Morphology, Corpus Scriptorum Christianorum Orientalium 267 (Louvain: Secretariat du CorpusSCO, 1966), 190 ff.; Adam Carter McCollum, "Garshuni as It Is: Some Observations from Reading East and West Syriac Manuscripts" (Hugoye: Journal of Syriac Studies 17:2 [2014]), 223. Especially for spelling irregularities due to the pressure of both Middle Arabic and Syriac environment, cf. Kessel, "Book of Grace", 12425 .

${ }^{41}$ George Grigore, L'arabe parlé à Mardin - Monographie d'un parler arabe «périphérique» (Bucarest: Editura Universității din Bucureşti, 2007), 124-25. 


\section{4 يُيقىى = نُحَمس}

The Garšuni spelling suggests it be read as $y u b q a \bar{a}$, i.e. as a I or IV passive form.

\section{صَعب وواقف ومضر = رَحد 400 أمف مدنز; 4}

Being the predicates of the verb baqiya, these nouns should have the tanwin al-fath of the accusative case. Its absence, though, is not worrying since it is common in Middle Arabic texts, where it is retained only as an ending for adverbs. For the use of wäqif with kaläm, see the Supplément aux dictionnaires arabes by Dozy. ${ }^{42}$

\section{4 مضنز}

There are several possible readings of this word. One is madar 'piece of dry or tough clay', and it could suggest a comparison: '[tough as] a piece of clay'. From the same root, it could also be an adjective, not attested elsewhere, meaning 'tough [as a piece of clay]'. Otherwise, considering that in Middle Arabic dall can sometimes be spelled with a $d \bar{a} l^{43}$ the reading madir, which means 'corrupt, rotten, spoiled', is acceptable. A third possibility, which was chosen for the translation, is to consider dalad an aberrant Garšuni spelling of däd. We would thus have the IV form passive participle mudarr from the root DRR, 'harmed, damaged, spoilt' or, if active, 'harmful, detrimental'. McCollum states that the spelling of dẹd with Syriac dälad is extremely rare in the manuscripts he surveyed, and it tends to appear more frequently in inscriptions. ${ }^{44}$ Conversely, and amusingly enough, in the same journal issue, Moukarzel says

42 Reinhart Pieter Anne Dozy, Supplément aux dictionnaires arabes, 3rd ed. (Leyde, Paris: Brill, Maisonneuve et Larose, 1967), 835.

43 Blau, A Grammar of Christian Arabic I, $107 \mathrm{ff}$.

${ }^{44}$ McCollum, "Garshuni as It Is,” 223. 
that this is the norm in the older Garšuni manuscripts, and provides the example of MS London, British Library, Add.

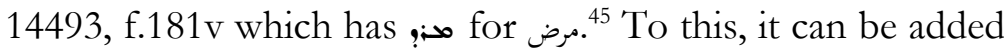
that the shift from $\mathbf{d}_{\bar{a}} \mathrm{~d}$ to dāl is attested in Middle Arabic too. ${ }^{46}$

\section{4 وَضَعُو = مَلَحُه}

This word poses many problems. The Garšuni text can be read as both a fo and aro, and the first wāw can be either a conjunction or the first radical. Considering the waw as a conjunction, the word can be read in several ways, but only zalli 'to be, become, transform' or 'to maintain, assert' fits in the context. However, if this were the case, the syntactical function of the waw following li-ăgl datika would not be clear. On the other hand, if the first waw is considered as the first radical, the only possible root is $\mathrm{WD}^{\text {c }}$ 'to put, lay down, fix; to establish, produce, create; to devise, invent'. In this case the subject would not be "the six letters" (in the following line), but instead an implied the speakers/users/Syrians. The use of an implied subject is more likely than an internal passive verbal form. Thus, wada $\bar{u}$ is to be understood as a third-person masculine plural lacking the aliffạsila. This is quite common in Middle Arabic spelling ${ }^{47}$ and can also be due to the Syriac orthographic influence via Garšuni. ${ }^{48}$ It occurs frequently throughout the Notice, so I will not point it out each time.

\section{5 تترككّخ = مازمتّم}

This is clearly an error for $\boldsymbol{0}$;LL, with two kaph fully written in addition to the $\check{s} a d d a$. For the use of this root, see above.

\footnotetext{
45 Moukarzel, "Maronite Garshuni Texts,” 253.

${ }^{46}$ Blau, A Grammar of Christian Arabic I, 223.

47 Blau, 35.

48 McCollum, "Garshuni as It Is," 229.
} 


\section{5 وتتقشّا = منانامقّا}

The alif maqșirra represented by alap instead of yod is a spelling influenced either by Middle Arabic ${ }^{49}$ or Garšuni. ${ }^{50}$

\section{6 | ويوضعوا =}

Cf. efo in line 4. This can be a passive imperfect of the I form, even though it lacks the num ending and is provided with an alif fassila. Strictly speaking, we would expect the form to be a subjunctive or an apocopate, but the mood distinction (and the num in the endings even in the imperfect) was lost in the spoken varieties of the language and affects also Middle Arabic texts. As a consequence, forms with or without the nun became variants. ${ }^{51}$ The Notice displays a language which has a clear preference for endings without nün.

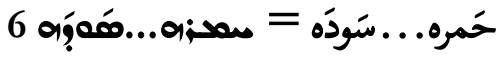

Worth noting here is the spelling of alif mamdīda with a be, which probably stands for a $t \bar{a}$ marbutta. That does not come as a surprise, because this spelling is quite common in Middle Arabic under the influence of pronunciation. ${ }^{52}$ Even if I did not find any other mention of the phenomenon, I suppose that this might depend on Garšuni itself, which usually overlooks final hamzas, and it might be the case that the scribe perceived the $t \bar{a}$ ' marbüta as a "universal feminine ending".

${ }^{49}$ Blau, A Grammar of Christian Arabic I, $81 \mathrm{ff}$.

50 McCollum, "Garshuni as It Is," 229.

51 Joshua Blau, A Grammar of Christian Arabic. Based Mainly on South Palestinian Texts from the First Millennium. Fasc. II: $\iint$ 170-368. Syntax I, Corpus Scriptorum Christianorum Orientalium 276 (Louvain: Secretariat du CorpusSCO, 1967), 259.

52 Blau, A Grammar of Christian Arabic I, 34; McCollum, "Garshuni as It Is," 234. 


\section{كانة = مادة 8}

This is to be read, of course, as kanat. Cf. the previous entry for the common use of $t \bar{a}$ ' marbutta in place of other feminine endings.

\section{ولو ما = محه ما 9}

It needs to be understood as if it were $i \underline{d} \bar{a} m \bar{a}$, but I have not found any reference to this phenomenon in Blau's description of Middle Arabic.

\section{كثير = مئم; 9}

Middle Arabic, like many dialects (with $\underline{t}>t$ ), prefers this form to the more classical ğiddan.

\section{كنت تقدر تقرا = فئه نامن; نام:| 10}

Kana governing the imperfect is very common in Middle Arabic, partly as a result of the influence of the Aramaic construction participle $+h w a \bar{a}$, and, as in Aramaic, it can mark hypothetic actions. ${ }^{53}$ The auxiliary verb qadara is followed by the verb qara' $a$ which, as we would expect, is also in the imperfect.

\section{هولاي = 12}

This is a Middle Arabic spelling for the Classical ha'ula'?. It is not possible to establish whether the hamza on the waw was still perceived or (more probably) not, only on the basis of the Garšuni spelling. Worth mentioning is the final yod, which can represent both a consonantal $y \bar{a}$ or an alif mamdüda for a

53 Blau, A Grammar of Christian Arabic II, $434 \mathrm{f}$. 
maqșüra. ${ }^{54}$ In the text one can also find the spelling $h w l$ ' in line 14, without the final yod. In line 17 there is a sign, after the alap, which I have not been able decipher; it could be an attempt to represent the final hamra.

\section{احروف = أمنمف 13}

The pattern af $\bar{u} \bar{l}$ (here, ahrüf) instead of $f u$ ' $\bar{u} l$ is already known in Middle Arabic, and it has been interpreted as the addition of a prosthetic vowel - represented by the hamza - to a previously weakened form $f^{c} \bar{u} l$. Otherwise, it can also be explained as a merging of the two Classical patterns $f u$ ' $\bar{u} l$ and $a f^{c} u l^{55}$ This latter appears in the Notice (as aḥruf) in line 45, whereas the heavy or mixed pattern ahrüf is also found in line 43. In many places, though, and more frequently, one finds the more common and standard form hurüf (11. 15, 17, 18, 20, 33). Furthermore, the syntax of the numeral would be completely wrong in Classical Arabic, but in the Middle and Modern varieties it has become more and more common. Not only to place the $i$ daffa with the numeral (determined by the article) before the ma diud is the norm, but there is also a preference for the feminine form of the numerals. ${ }^{56}$ See also lines $14-15$ for the same phrase.

\section{سقطو على = مممهه دخد 14}

For an interpretation of this phrase, see the paragraph on linguistic interference.

\section{نَحُو = تَسُ 15}

The vocalisation given in the Garšuni text may suggest that the original third radical waw became, at a certain point, a full

\footnotetext{
54 Blau, A Grammar of Christian Arabic I, $136 \mathrm{ff}$.

55 Blau, 228.

56 Blau, 49.
} 
vowel, possibly as a consequence of the loss of the nominal declension $\left(n a h w^{\mu n}>n a h \underline{w}>n a h \underline{u}\right)$.

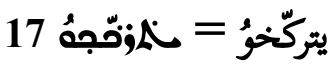

This verb might be an apocopate and fits with the syntax of an apodosis of a conditional period introduced by $i \underline{d} \bar{a}$ (line 16). However, the distinction between moods is unlikely in a Middle Arabic text (cf. comment to line 6). Its subject should be bülà('i) al-samā( ('), with a wrong agreement in the grammatical gender and number (i.e., the plural masculine of inanimate names is no more in agreement with the singular feminine). This is not surprising as it occurs frequently throughout the Notice. ${ }^{57}$

\section{وانما = مأسما 18}

Considering the overall meaning of the sentence, I suggest reading it as wa-in-māa, and not wa-innama $\bar{a}$, which would not make any sense. This must be a negative conditional and corresponds to the conditional phrase introduced by $i \underline{d} a$ in line 16. One would expect in lam, but it seems that lam disappeared early in speech whereas $m \bar{a}$ became the most used negative adverb. $^{58}$

\section{9 ?}

This is, of course, a Syriac word, i.e. the one used to introduce comparisons or, as it is the case here, examples. It recurs often in the text to introduce examples, alone or together with the particle $d$-; there are a couple of other Syriac syntagmata used in the examples. Here a complete list of the occurrences:

1. ak $d$-, 'as, like' - 1l. 19, 20, 25, 26, 27, 33, 352, 36, $37,39^{3}, 40,42^{2}, 44,46,47,49,52,55,58$

${ }^{57}$ Cf. Blau, A Grammar of Christian Arabic II, 275.

58 Blau, A Grammar of Christian Arabic I, $203 \mathrm{f}$. 
2. $w$-šarka a, 'and the rest, etc.' $-27,40$

3. sțar men, 'except for' - 40, 58, 61

Particularly interesting is line 40 , where there is an entire phrase in Syriac: $w$-šarkea $w$-d-ak hälèn star men, 'and the rest like them, except for', where the pronoun is also in Syriac. ${ }^{59}$

\section{4 واضراب = lifo}

Here one would expect to find çurüb, the broken plural of darb meaning 'kind, species, variety', whereas in Classical Arabic $a d r a \bar{b}$ is the plural of the same word meaning 'similar, alike'. This can be explained perhaps by the widespread fortune of af'al-like plurals in Middle Arabic, which preferred them to the other patterns, even when a noun did not have it in the classical language. If this were not the case, the text can also be understood as follows: "Concerning the $p \bar{e}$, it has three varieties and similar [forms]".

\section{ومقشيه = مممقصمه}

One would have expected a passive form, which is possible for , ממ:مصه which precedes it, but not for according to classical grammar. As a verb of $\mathrm{C}_{3}$ weak (näqis, 'defective'), it should have been muqašsahh, with an alif of prolongation followed by a $t \bar{a}$ ' marbutta. There are two possible explanations: either the active form simply means 'that takes the rukkeakea $\vec{a}$ qušs $\bar{a} y \vec{a}$ (and sometimes further in the text I had to translate some active forms with 'to be pronounced fricative/plosive'); or a feminine passive form like muqaššăh

${ }^{59}$ For other examples of the use of Syriac phrases surrounding Syriac words quoted within a Garšuni context, cf. Tijmen C. Baarda, "Standardized Arabic as Post-Nahḍa Common Ground: Mattai Bar Paulus and His Use of Syriac, Arabic, and Garshuni," in Modernity, Minority, and the Public Sphere: Jews and Christians in the Middle East, ed. S.R. Goldstein-Sabbah and H.L. Murre-van den Berg (Brill, 2016), 85. 
have shifted in Middle Arabic to a more simplified form which retains the $y \vec{a}$ ' as $\mathrm{C}_{3}$ and simply adds the feminine $t \vec{a}$ marbutta.

\section{ليس = حمس 30}

The negative verb laysa, already defective (ğàmid, 'stiffened') in Classical Arabic, became invariable in Middle Arabic. ${ }^{60}$

\section{6 الاخرانيّه = اللاص:أنّه}

The alif uhraniyya has been already addressed in the discussion above. Here it is worth noting that this is not a Classical form, but I suspect that it has been coined after the form illani, for which see in line 52. Since this latter clearly means "first", and if it is true that uhräniyya follows the same pattern of ülaniyya, I think that the translation of "second, following, in second position" rather than "last, coming at the end" is preferable.

\section{المئكثر = الحمّمهي; 47}

In the Garšuni text the sadda-like sign is definitely on the first tâw. However, the only way I can explain this form is to move it to the second one (it is not infrequent for the Notice's scribe to place the $\check{s} a d d a$ not right above the doubled letter) and read it as a $\mathrm{V}$ form participle al-mutakattir. Nonetheless, the meaning does not fit with the context. I suspect that we should regard it as a parallel of the Syriac saggiyuta, meaning thus 'plural [form]', probably via 'augmented, multiplicated [form]', as the overall meaning of the sentence suggests.

\section{دايم =}

A colloquial form from a more Classical dásiman in the adverbial accusative.

${ }^{60}$ Blau, A Grammar of Christian Arabic II, $305 \mathrm{ff}$. 


\section{الثاو ساكته = الحئه مافئه}

This phrase presents two problems. Firstly, in the name of the letter in the Garšuni text there clearly is a rukekake under the tâw. Secondly, there is no determination agreement between the noun and the adjective, which lacks the definite article. I translated as if it were al-täw al-säkita. The adjective can also be regarded as a sifa ('the tāw which is quiescent').

\section{الاولاني = اللاهلاس 52}

This word does not exist in Classical Arabic. It is however documented at least in the sámi dialect. $^{61}$

\section{تتقشي = نانامس}

It should be a II form since its subject is the wain which, of course, cannot undergo lenition nor hardening.

\section{CONCLUSIONS}

Even if the Notice lends itself to several comments, the text and content analysis provides very little information about the nature, the purpose and the tradition of the text, apart from what is stated in the colophon. Through a comparison of the treatise with other Syriac native grammars ( $(3)$, it would appear that the former is a somewhat abridged description of the topic and is more concise than those included in the Metrical Grammar by Bar 'Ebrāyā and in the major Syriac grammars. The use of highly specialised vocabulary (both Arabic and Syriac, \$4) leads, on the one hand, to suppose that it was aimed at learned and well-skilled readers (i.e. the Notice was not meant as a beginner textbook), and, on the other, to consider the Notice as a brief memorandum about the main rules governing

61 Adrien Barthélemy, Dictionnaire arabe-français. Dialectes de Syrie; Alep, Damas, Liban, Jérusalem (Paris: P. Geuthner, 1935), 20. 
the pronunciation of bgädkpät. It might even be regarded as an improvised diversion of the scribe.

This last hypothesis seems to be partly supported by the interpretation of the statement in the colophon $(\$ 1)$ in which qadmá 'it can mean 'originally'. However, even if the Notice was not 'originally' intended to be part of the anthological manuscript, it could still have been copied by an existing antigraph. Some indications of this can be found in the content analysis of the text. In fact, a couple of muddled passages ( $(2)$ seem to suggest that scribal errors may have taken place. Inconsistencies and a margin of error can of course be due to the concise nature of the text (as in lines 45-50), but sometimes I suspect a saut du même au même (as in lines 44-45).

Conversely, a significant amount of information can be gathered about the language of the Notice, i.e. a Middle Arabic variety in Garšuni script. Although these two phenomena do not represent the same thing, we can assume that they would interlock in a text written by a Christian scribe. Some elements of the text suggest that Garšuni script tends to intensify several features which are typical of Middle Arabic. It can also be assumed that Syriac, thanks to Garšuni, may have exerted a greater influence on the "intermediate, multiform variety [i.e. Middle Arabic], product of the interference of the two polar varieties [fuṣha and dialect] on the continuum they bound". ${ }^{62}$ An example of this two-way influence is the spelling of șaql as saql. It is difficult to establish definitively to what extent it can be regarded as a phonetic feature which is a characteristic of Middle Arabic (simplification of emphatic sounds), or whether it should be ascribed to the impact of the Syriac word seqla (see the comment to line 1). As far as the impact of Syriac is concerned, I have been able to identify Syriac as the source of non-literary and non-dialectal Arabic features. This is particularly true with reference to technical lexis $(\$ 4)$, which shows a high degree of permeability to external pressure and

${ }^{62}$ Jérôme Lentin, "Middle Arabic," Encyclopedia of Arabic Language and Linguistics (Leiden: Brill, 2008), 216. 
neologisms. Given the close connection between the writing system (Garšuni) and the language (Middle Arabic) and the possible conditioning of the former on the latter, it becomes an attractive hypothesis that Garšuni

might have indicated, in its beginning, a colloquial form of Arabic used in verbal communications. [...] This vernacular Arabic spoken in everyday life by Arab new-comers, and by then also commonly used by Christian people, being a common, non-literary form of Arabic, did not need a formal, Arabic script. On the contrary, the choice of the Syriac script was perhaps a way to differentiate between 'classical, learnt from books' and 'non-classical, spoken' Arabic. ${ }^{63}$

Braida's statement is largely sharable, with certain reservations about strict separation between spoken and literary Arabic, as it does not consider the Middle variety of the language. ${ }^{64}$ The scientific community still needs a complete survey and comparison of all the existing and available Garšuni texts in order to draw more general conclusions. However, there is no doubt that the use of Garšuni was not just a matter of calligraphic choice (as a result of a national or cultural identity statement, for example). It can be also suggested that it might have often led to the use of specific linguistic features, namely a certain degree of dialectal and/or Syriac influence on the Arabic structure. This is exactly what happens in Middle Arabic texts. With reference to this aspect, it is worth noting

63 Emanuela Braida, "Garshuni Manuscripts and Garshuni Notes in Syriac Manuscripts,” (Parole de l'Orient 37 [2012]), 192.

${ }^{64}$ Which is, of course, in the case of Arabic, a longstanding vexata quaestio. A summary of it, with a first bibliography, in Lentin, "Middle Arabic". See also, for some interesting considerations, Hary Benjamin, "Middle Arabic: Proposal For New Terminology," (Al-'Arabiyya 22:1/2 [1989]), 19-36. 
with $\mathrm{McCollum}^{65}$ that, in the colophon, the scribe of MS Jerusalem, Saint Mark Monastery (SMMJ), 167 (dated 1882 $\mathrm{CE})$ refers to "the language of Garšuni" (lisān al-garšñ i). The use of the word lisān 'language' is striking here, even though the process which is referred to is not one of translation (tarğama) but of transcription (nash). This fact sheds some light on the position of Garšuni, which is mainly in opposition to Arabic because of the use of Syriac script. However, it is also formally recognised as a language, although its status is doubtful. In fact, a Garšuni text is a result of transcription of an original Arabic and not of translation. This analysis is also in line with the observation by Harrak on the Syriac inscriptions from Iraq, where-he writes - the process of sophistication of the language during the nineteenth century corresponded to the decline of the use of Garšuni, up until the twentieth century, when there is no evidence of production of Garšuni inscriptions. ${ }^{66}$

By contrast, we also need to mention the fact that the use of Garšuni does not imply ipso facto the use of a middle variety of the Arabic language. This is true in cases like the Syriac translation by Bar 'Ebrāyā of Ibn Sinnā's Kitāb al-išārāt wa-'tanbihät, which is provided as a parallel text alongside the original Arabic. ${ }^{67}$ Even if in the most ancient witness the Arabic text is given in Arabic characters, ${ }^{68}$ in the other manuscripts preserving the complete text the Arabic is in Garšuni. ${ }^{69}$ Therefore, we have an Arabic text written in fusḥa

${ }^{65}$ McCollum, "Garshuni as It Is," 226.

66 Amir Harrak, Syriac and Garshuni Inscriptions of Iraq, vol. 1, Recueil Des Inscriptions Syriaques 2 (Paris: De Boccard, 2010), 43. For an interesting discussion of this assessment and of the Garšuni/Middle Arabic/Syriac issue, especially in the nahda period, cf. Baarda, "Standardized Arabic as Post-Nahḍa Common Ground: Mattai Bar Paulus and His Use of Syriac, Arabic, and Garshuni," 86 ff., where I also firstly read about Harrak's considerations.

${ }^{67}$ I thank Prof. P.G. Borbone for having pointed that out to me.

${ }^{68}$ MS Firenze, Biblioteca Medicea Laurenziana, Or. 86.

${ }^{69}$ Cf. for a complete reference list: Hidemi Takahashi, Barbebraeus: $A$ Bio-Bibliography (Piscataway: Grogias Press, 2005), $266 \mathrm{f}$. 
using the Garšuni scripture. A few other considerations can be made. Firstly, the only manuscript using Arabic characters is also the only extant manuscript copied during the lifetime of Bar 'Ebrāyā, whereas the Garšuni copies date back to at least the fifteenth century; secondly, this work was not originally written in Garšuni, but is rather a Muslim philosophical treatise which was copied next to the Syriac translation. It is clear that the discussion about the status and role of Garšuni is still wide open.

Finally, we can say that the Notice is an outstanding example of the interdependence between different linguistic strata (the classical and the spoken) that is characteristic of a Middle Arabic variety. Furthermore, the pressure exerted by Syriacin terms of both the content and the cultural environmenthighlights a significant degree of internal differentiation of Middle Arabic. Clearly, Middle Arabic is not a fixed literal standard, but it can be best described as a "bundle" of many varieties sharing common features, differentiated by the influence of external factors (religious community, geography, and so forth).

\section{BIBLIOGRAPHY}

Baarda, Tijmen C. "Standardized Arabic as Post-Nahḍa Common Ground: Mattai Bar Paulus and His Use of Syriac, Arabic, and Garshuni." In Modernity, Minority, and the Public Sphere: Jews and Christians in the Middle East, edited by S.R. Goldstein-Sabbah and H.L. Murre-van den Berg. Brill, 2016.

Barthélemy, Adrien. Dictionnaire arabe-français. Dialectes de Syrie; Alep, Damas, Liban, Jérusalem. Paris: P. Geuthner, 1935.

Benjamin, Hary. "Middle Arabic: Proposal For New Terminology.” Al-'Arabiyya 22, no. 1/2 (1989): 19-36. 
Blau, Joshua. A Grammar of Christian Arabic. Based Mainly on South Palestinian Texts from the First Millennium. Fasc. I: $\iint 1$ 1169. Introduction-Orthography \& Phonetics-Morphology. Corpus Scriptorum Christianorum Orientalium 267. Louvain: Secretariat du CorpusSCO, 1966.

A Grammar of Christian Arabic. Based Mainly on South Palestinian Texts from the First Millennium. Fasc. II: $\iint \mathbb{\int} 170-368$. Syntax I. Corpus Scriptorum Christianorum Orientalium 276. Louvain: Secretariat du CorpusSCO, 1967.

Braida, Emanuela. "Garshuni Manuscripts and Garshuni Notes in Syriac Manuscripts." Parole de l'Orient 37 (2012): 181-98.

Butts, Aaron Michael. Language Change in the Wake of Empire: Syriac in Its Greco-Roman Context. Linguistic Studies in Ancient West Semitic 11. Winona Lake: Eisenbrauns, 2016.

- "The Integration of Consonants in Greek Loanwords in Syriac." Aramaic Studies 14 (2016): 1-35.

David, Clemens Joseph. Grammatica aramaica seu syriaca philologice exposita juxta utrumque systema, orientale scilicet et occidentale. Mosul, 1896.

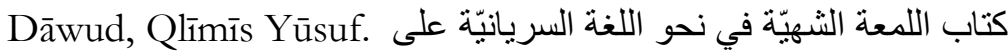
. Kitāb al-lum'a al-šahiyya fì naḥw allugia al-suryāniyya 'alà kilā madhabay al-g̈arbiyyin wa-'-šaraiyyin. Mosul, 1879.

Dozy, Reinhart Pieter Anne. Supplément aux dictionnaires arabes. 3rd ed. 2 vols. Leyde, Paris: Brill, Maisonneuve et Larose, 1967.

Duval, Rubens. Traité de grammaire syriaque. Paris: F. Vieweg, 1881. 
Gacek, Adam. Arabic Manuscripts: A Vademecum for the Readers. Handbook of Oriental Studies. Section 1, The Near and Middle East 98. Leiden, Boston: Brill, 2009.

Grigore, George. L'arabe parlé à Mardin - Monographie d'un parler arabe «périphérique». Bucarest: Editura Universităţii din Bucureşti, 2007.

Harrak, Amir. Syriac and Garshuni Inscriptions of Iraq. Vol. 1. 2 vols. Recueil Des Inscriptions Syriaques 2. Paris: De Boccard, 2010.

Kessel, Grigory. "The Importance of the Manuscript Tradition of the 'Book of Grace' for the Study of Garšunnī." Parole de l'Orient 37 (2012): 199-222.

Kiraz, George Anton. Introduction to Syriac Spirantization, Ruk.kâkâ and Qušsâyâ. Losser: Bar Hebraeus Verlag, 1995.

Lentin, Jérôme. "Middle Arabic." Encyclopedia of Arabic Language and Linguistics. Leiden: Koninklijke Brill NV, 2008.

Maqdisī, Jeremiah. Grammaire chaldéenne. Mosul, 1889.

McCollum, Adam Carter. "Garshuni as It Is: Some Observations from Reading East and West Syriac Manuscripts." Hugoye: Journal of Syriac Studies 17, no. 2 (2014): 215-35.

Merx, Albertus. Historia artis grammaticae apud Syros. Kunde Des Morgenlandes 2. Leipzig: Deutschen Morgenländischen Gesellschaft, 1889.

Mingana, Alphonse. Clef de la langue araméenne ou grammaire complète et pratique des deux dialectes syriaques occidental et oriental. Mosul, Paris, 1905. 
Moberg, Axel. Le livre des splendeurs. La grande grammaire de Grégoire Barbebraeus. Texte syriaque édité d'après les manuscrits avec une introduction et des notes. Vol. IV. Skrifter Utgivna Av Kungliga Humanistiska Vetenskapssamfundet i Lund. London, Paris, Oxford, Leipzig: Humphrey Milford, Édouard Champion, University Press, O. Harrassowitz, 1922.

Moukarzel, Joseph. "Maronite Garshuni Texts: On Their Evolution, Characteristics, and Function." Hugoye: Journal of Syriac Studies 17, no. 2 (2014): 237-62.

Nöldeke, Theodor. Compendious Syriac Grammar. Translated by James A. Crichton. London: Williams \& Norgate, 1904.

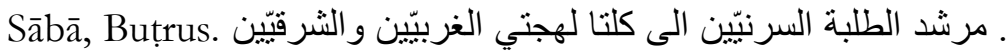
Muršid al-țalaba al-suryāniyyín ilā kiltā lahğ atay al-garbiyyin wa'l-šarqiyyin. Beirut: al-Mațba'a al-Kātūūîkiyya, 1948.

Sachau, Eduard. Verzeichniss der syrischen Handschriften. Vol. 1-2. 2 vols. Die Handschriften-Verzeichnisse der Könighlichen Bibliothek zu Berlin 23. Berlin: A. Asher \& Co., 1899.

Takahashi, Hidemi. Barhebraeus: A Bio-Bibliography. Piscataway: Grogias Press, 2005.

Voigt, R. "Das emphatische $\mathrm{p}$ des Syrischen." Symposium Syriacum VII, Orientalia Christiana Analecta, 256 (1998): 527-37.

'Amīra, Ğ irğ is Mihāāīl. Grammatica syriaca sive chaldaica. Roma: Giacomo Luna, 1596. 